\title{
Cherry Picking Disability Rights? Swedish Disability Policy on Employment, Health and Participation'
}

\section{Faten Nouf-Latif ${ }^{2}$}

Phd student, Umeå University, Department of Social Work, Sweden

\section{Katarina Andersson}

Associate professor, Umeå University, Department of Social Work, Sweden

\section{Urban Markström}

Professor, Umeå University, Department of Social Work, Sweden

\begin{abstract}
The aim of this article is to broaden the understanding of how Swedish disability policies are constructed to meet the objectives of the ratified UN Convention on the Rights of Persons with Disabilities (CRPD) regarding active citizenship and full participation on an equal basis with others. The study examines two policy domains: health and employment. Recently issued legal documents are analyzed using the approach of directed content analysis and the theories of 'social risk' and 'governance'. The results suggest that the policy area of employment implicitly and explicitly overshadows the policy area of health and related rights accounted for in the CRPD. A more nuanced perspective in disability policies concerning employment in relation to active citizenry and full participation is required, accompanied by social policy schemes that encompass the perspective of the CRPD as a whole in all support-towork services, instead of the limited focus of finding full-time employment.
\end{abstract}

\section{KEYWORDS}

Active citizenship / CRPD / Disability policy / Employment / Full participation / Governance / Health / Social risk / Sweden

\section{Introduction}

After work I go home, possibly make a meal, but most often I just buy a yoghurt on my way home. Work takes everything I've got. I don't have anything else outside of work/ ... / nowadays, both parties in a relationship must work fulltime! And do everything else in life, and that only leads to people getting burnout, becoming unemployed, or going on sickleave and using rehabilitation services. So that is what I think of when I think about 'work,' which is not the fanciest thing you can accomplish in life! [woman, 35].

he UN Convention on the Rights of Persons with Disabilities (CRPD) was ratified by Sweden in 2008. It serves to safeguard individual wellbeing for people with disabilities and their enjoyment of - and participation in - all important life areas considered as human rights. Article 1 in the CRPD states:

\footnotetext{
${ }^{1}$ You can find this text and its DOI at https://tidsskrift.dk/njwls/index.

${ }^{2}$ Corresponding author: Faten Nouf-Latif. Faten.nouf@umu.se.
} 
The purpose of the present Convention is to promote, protect and ensure the full and equal enjoyment of all human rights and fundamental freedoms by all persons with disabilities/... /which in interaction with various barriers may hinder their full and effective participation in society on an equal basis with others.

Mental health problems are the most common reason for applications for disability benefits in many European countries, including Sweden (OECD 2010, 2015). The introductory quotation illustrates an example of the research problem we seek to understand through the conduct of this study, where wellbeing, or health, is challenged by fulltime work/occupation. The quotation is taken from a larger research project on highfunctioning adults with autism and work-life. Narratives such as the one above were the impetus to the present paper, where the otherwise uncontested logic of 'full employment' is the focus. We can view this research problem, theoretically, as a tension between the right to paid employment on the open labor market and the obligation to work (cf. Nouf-Latif et al. 2019a). The concepts of health and work are examined in this context as having interrelated consequences for each other, for example, the notion that health, or wellbeing, is affected by different aspects of work and work-life (Clark 1998; NoufLatif et al. 2019a, 2019b; Pagán 2007; Pearson 2008; Yeh 2015).

The International Classification of Functioning, Disability and Health (ICF) provides detailed descriptions and measures of the notion of 'participation' and upholds the importance of a diverse range of types of participation(s), including participation in community, social and civic life, domestic life, self-care, interpersonal interactions and relationships, and other major life areas. ICF also raises awareness of the impact that contextual factors have on health and wellbeing, such as formal structures and services (WHO 2001, p. 14-17). 'Health' in the present paper is used in line with the ICF definitions of the term, which encompass several life areas that are crucial to wellbeing, including working life. However, health and employment are separated in policies in the sense that they constitute different policy areas and are steered by different government ministries.

The overarching aim of this article is to broaden the understanding of how employment and health are merged in Swedish disability policies and, additionally, how the policy areas are managed in order to meet the national CRPD-influenced goals of full participation.

Social research on employment and people with disabilities commonly highlight notions of social inclusion and community participation as imperative for the welfare of individuals with disabilities, which can partly be achieved through the right to equal participation on the labor market as nondisabled (Barnes 2000; Barnes \& Mercer 2005). This goal is high on the Swedish disability policy agenda. Research can be found in the area of disability studies where the right to have a job on equal terms with nondisabled citizens has been a core issue and an important issue driven by disability movements for several decades (cf. UPIAS 1976; Beresford \& Holden 2000). Rights for people with disabilities in relation to employment and work can also be found in the CRPD:

States Parties recognize the right of persons with disabilities to work on an equal basis with others; this includes the right to the opportunity to gain a living by work freely chosen or accepted ... (UN CRPD 2006, Article 27). 
The convention also calls for the 'enjoyment of the highest attainable standard of health without discrimination on the basis of disability' in Article 25, which is written in more general terms and highlights issues of early interventions and health-related rehabilitation. The issue of habilitation or rehabilitation is also represented in Article 26 with the aim to:

... enable persons with disabilities to attain and maintain maximum independence, full physical, mental, social and vocational ability, and full inclusion and participation in all aspects of life. To that end, States Parties shall organize ... programmes, particularly in the areas of health, employment, education and social services, in such a way that these services and programmes ... are based on the multidisciplinary assessment of individual needs and strengths ... [and] are voluntary ... (UN CRPD 2006, Article 26).

Rehabilitation services, thus, target all life areas that can be improved, or alleviated, to achieve better health, that is, individual wellbeing through habilitation or rehabilitation is viewed from a holistic perspective.

The most recent Swedish Governmental Proposal (GP) on Disability Policy is the main document analyzed in this paper. It states that the goal of Swedish disability policy is in line with the UN convention and aims to achieve 'equity in living conditions' and 'full participation' in society for people with impairments (Prop. 2016/17:188, p. 24-25). The CRPD principle of effective participation and inclusion in society is accounted for in the document, which states that society in the general and private arenas should be organized so that all people have the potential to be full participants and that public actors recognize them as equal participants in all decision-making processes that affect their lives (Prop. 2016/17:188, p. 16). The concepts 'full participation' and 'equal participation' coincide with the definitions in the CRPD (see UN CRPD 2006, Preamble, Article 3). However, for the sake of brevity, the concept 'full participation' in this paper will refer to full and effective participation on an equal basis with others.

The theoretical concept of 'active citizenship' comprises issues of work, health and autonomy (Bickenbach 2017; Hvinden 2017). In relation to people with disabilities, active citizenry applies to notions of self-agency, that is, self-determination, control, selfrealization and pursuits in life. The meaning of the concept is closely related to the rights in CRPD that target the empowered citizen, who is an active participant in all parts of their community (see Lister 2003; Lister et al. 2011; Bickenbach 2017; Hvinden et al. 2017). Active citizenry, consequently, precedes full participation.

Among people with disabilities in Sweden, discrimination, lack of social influence and economic insecurity are reported to be the main causes of poor health. Additionally, only $42 \%$ of people with disabilities in Sweden have reported good health, compared to $82 \%$ of the general population (Prop 2017/18:249, p. 13). In addition, $34 \%$ have reported that they have no social, political or recreational activities, compared to $15 \%$ of the nondisabled population. (Prop. 2016/17:188, 11-12). Sixty-two percent of persons with disabilities have reported having a job (compared to $40 \%$ in Europe, cf. Sainsbury et al. 2017) compared to $78 \%$ of the general Swedish population. The prioritization of labor market participation, in line with expectations on citizens' moral responsibility to work (e.g., Kvist et al. 2012), remains the most central policy approach in national policy-making intended to achieve full participation for adults with disabilities. There is a potential conflict of interest between individual welfare and policy constructs in 
relation to the CRPD. This conflict makes it important to understand how ongoing work with health and employment in Swedish disability policy is managed to achieve the goal of active citizenry and full participation. The research questions in the present study are

(1) How are individuals with disabilities described in terms of social citizens in the policy areas of health and employment, and what responsibilities are they ascribed?

(2) How are governmental responsibilities formulated in the GP, and how are they governed by health and employment policies?

(3) How does policy management in each policy area affect individual opportunities to enjoy active citizenry, CRPD and, thereby, full participation?

\section{Full participation through work in the Nordic countries}

The Nordic countries handle disability policies differently in relation to the goal of full participation. However, in general, full-time employment has attracted a great deal of attention in national policy making, both by being a tool used to manage social expenditures (Kvist et al. 2012) and to attain compliance with the CRPD (Prop. 2016/17:188). Public policy is designed to enable people with impairments to exercise agency, or to take control of important matters in life, that is, to enable active citizenry (Hvinden et al. 2017, p. 3). Active citizenship describes the empowered and autonomous individual who is a bearer of rights and social obligations and has the responsibility to make adequate choices in relation to him/herself and the community, for example, through labor market participation (Melén 2018; Newman \& Tonkens 2011; Wright 2012). As Halvorsen et al. (2017) highlight, labor market participation has come to make a strong claim on active citizenry in disability policies. Even though the concept active citizenship is not explicitly used in social policies, its meaning is put into practice through diverse social policy schemes (Hvinden et al. 2017), and its purpose is to strive for people with disabilities to achieve full participation.

The Nordic countries can be classified a 'family of their own' when it comes to low rates of poverty and equal levels of income distribution in comparison to other western countries. However, new social risk groups of young single adults and immigrants form a poverty group that is more similar to other western societies and falls outside the traditional good poverty management of the Nordics (Fritzell et al. 2012). Among these young adults, we have a growing group of unemployed people with disabilities (e.g., Halvorsen \& Hvinden 2014). Denmark, Norway and Sweden have higher labor market participation among disadvantaged groups in comparison to liberal regimes, such as the UK and Ireland (Sainsbury et al. 2017). As Piippola describes (2010), Sweden has a strongly driven labor market policy [Arbetslinjen]. The characteristics of this political model focus on individuals' flexibility on the market, instead of the employment system's flexibility, as is the case in Denmark (Madsen 2008). Individual flexibility is encouraged through support-to-work schemes, such as internships, education and geographic mobility (Piippola 2010).

Meanwhile, there are life areas other than work-life that, in line with, for example, the Swedish Disability Movement's directed critique, are undermined by a focus on, for example, the labor market domain (Åkerberg 2011, p. 24). However, the management of policies is a matter of political priorities, which will be presented next.

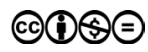




\section{Policy Management and 'Social risk'}

Since the term social risk, per se, is not explicitly used in policy documents, a brief presentation of the concept and its implications for policy constructs is necessary, as we will use the concept as an analytical framework for our findings.

In modern society, social risk has become a socially constructed term used to communicate the probability of an identified 'hazard' to happen. The hazard is culturally or socially constructed, and must be managed through policies (Esping Andersen 1999; Lupton 1993):

Definitions of risk may serve to identify Self and the Other, to apportion blame upon stigmatized minorities, or as a political weapon. Risk therefore may have less to do with the nature of danger than the ideological purposes to which concerns about risk may be put (Lupton 1993, p. 428).

Social policies are, on the one hand, known for being changeable and having ideological underpinnings where new ideological norms replace old ones. Special legislation and welfare provisions for people with disabilities are products of the disability reform in Sweden that was built on a vision aimed at full inclusion and participation in society (Markström 2003). On the other hand, social policies are also products of contemporary perceptions of social risks, such as unemployment. Being out of work put people at risk of, for example, poverty and isolation, which becomes an issue of intervention for the state, and requires proper risk management through social policies. Risk management has taken great space in the infrastructure of welfare policies (Fritzell et al. 2012; Powell \& Barrientos 2004). The constructed policies, which serve to combat unemployment, vary in their nature/content, due to the assessed risk (degree of economic impact) in the present context of national economies (cf. Sainsbury et al. 2017; Esping Andersen 1999), which has given rise to the rationality of 'no rights without responsibilities' (Grover \& Soldatic 2013; Kemshall 2002, 2010; Lister et al. 2011). As people with disabilities constitute a citizen group with lower employment rates than the general public, they form a social risk group from multiple perspectives. Active Labor Market Policies (ALMP) aim to empower individuals through market integration, instead of passively protecting them from it through, for example, livelihood maintenance of different forms (Cantillon \& Van Lancker 2013).

There are different categorizations of posing a risk; one can either be 'at risk of' or 'pose a risk'. Health-style risks are an example of 'at risk of' that place the responsibility on individual subjects to make cautious choices, in order not to burden society with future complications and costs due to bad lifestyle choices (Kemshall 2002; Lupton 1993; Melén 2008). The public can be informed of risk factors as solely enlightening public information. But in other cases, when individuals 'pose a risk', a coercive form of imposition on human autonomy can be imposed through evaluations of deservingness (e.g., punitive sanctions in the labor market, cf. Kvist et al. 2012, p.7). The political management of risk by adopting a moralizing rhetoric constitutes a tool for taking control of citizens, triggering self-blame, fear, guilt and other negatively associated psychological factors (Lupton 1993). The goal is to motivate normatively correct and rational choices by individuals. However, as Kemshall (2010) explains, neglecting the differences between people's social contexts and life circumstances become visible since a person's 
ability and socioeconomic status enables or hinders that person from making the right choices and avoiding risks.

The concept of governance will be described in order to theoretically understand how policies, which are more or less prioritized (constituting different types of social risks), are managed in policy making.

\section{Soft and hard governance}

In this study, the theory of 'governance' provides with an understanding of how the Swedish disability policy goal of full participation is being achieved. One way to put governance into context is to say that it is advanced policy management that aims to control how organizations and citizens control themselves (Morén et al. 2015, p. 35). Governance encompasses an economic rationality where all choices by citizens and professionals have been foreseen by policymakers and managed through the construction of policy schemes (cf. Rose 1999). One way of categorizing different types of policy management is through the distinction between 'soft' and 'hard' governance as two different steering types. Soft governance is a political management that addresses knowledge distribution and unofficial guidelines for policy implementation at an organizational level. Hard governance is more about regulating social policies through detailed legislation and tailored policy-schemes to further ensure that policies are implemented in a certain way, or to control frontline agency compliance, that is, that state officials factually work in accordance with the basic purpose of a political goal (Brandsen et al. 2006; Maycraft Kall 2010, p. 12). Debates about the consequences of each form of steering are ongoing. One critique of soft governance, for instance, is that vague policy directives can be comprehended as scattered and unclear, which makes implementation hard in relation to what to implement and how to implement a policy (Brandsen et al. 2006; Mättää \& Eriksson 2014). One of the most highlighted positive outcomes is, nonetheless, the potential for professional discretion that comes with abstract directives, which is a professional and organizational freedom that can be used to prioritize local needs organizational or client needs - if the discretion is used in a proper way (cf. Evans \& Harris 2004; Brandsen et al. 2006). As Bergmark et al. (2017) describe, soft governance can also be a way of managing policy issues that are not easily resolved, and so the responsibility is delegated to the organizational level, which releases the government from liability if the results are unsatisfactory (Johansson 2011). Much of the critique of hard policies focuses on the loss of organizational and professional discretion and the defocus from identified client needs, caused by strict policy schemes. This issue is also related to the demands for productivity and efficacy of public organizations, which reduces professional discretion to a narrower form of standardized client management and predetermined work prioritizations (Johansson 2011; Morén et al. 2015).

\section{Methods}

We used a deductive approach in the present study where we analyzed the management of disability policies, in relation to employment and health, in the most recently issued legal documents. 'Legal documents' refers to official government documents publicly 
issued by the Swedish governments' different offices and that are part of the legislative process. The documents of interest in this paper have extensive relevance in the legislative process as representing the final stages of the legislative policy making chain [Government official Reports (GoR) and Government Proposals (GP)].

We searched for the legal documents on the government's homepage (www.regereringen.se). The selection criteria used in the search engine were (i) legal documents issued by the Ministries of Employment (MiE) and the Ministry of Health and Social affairs (MiSa); (ii) the policy areas of employment, public health and disability; (iii) document types of Government official Reports and Government Proposals issued in the timeframe of 2012-01 to 2019-01. The search generated 163 documents. We selected the documents that were the most up-to-date and dealt with both health and employment in relation to people with disabilities (some documents were solely about health or employment). A GP issued by MiSa in 2016 (Prop. 2016/17:188) is the main document of interest. It uniquely describes the national goals and strategies in the continuous work with disability policies. Three other legal documents were also analyzed and are discussed in the analytical section. These serve as referential documents in the paper, meaning that they were treated as a complement to compare and obtain further information on issues that were addressed, or seemed missing, in the main disability policy document. The first document examined is a GP issued by MiSa on good and equal health in Sweden. It targets the entire Swedish population, which includes the subgroup of people with disabilities (Prop. 2017/18:249). The second document is an extensive GoR that deals with employment and people with disabilities (SoU 2012:31). The third one is a GoR that is the most recent document on rehabilitation provisions and support-to-work schemes (SoU 2018:21). These four documents provided us with a merged picture of the governance of policies and political constructs and, additionally, the implications of full participation for individuals with disabilities.

The main document 2016/17:188 is divided into several chapters and is 92 pages long. Chapters 5 (p. 22-30) and 7 (p. 34-72) are of particular interest in this study. The summarizing formulations of goals and strategies in the main document facilitate an understanding of what goals the government finds most important to uphold in each policy area of disability policy and how the main strategies for realizing these visions are formulated. Despite the focus on Chapters 5 and 7, the rest of the document was also read thoroughly, and relevant parts containing general formulations of goals in national disability policies in relation to employment, health and health-related aspects were analyzed as well.

We used a methodology inspired by directed content analysis when analyzing legal documents targeting health and employment (see Hsieh \& Shannon 2005). In line with directed content analysis, relevant chapters were first read iteratively. These chapters targeted (a) general formulations/descriptions of disability policies and (b) national goals and strategies in public health and employment. Second, we reduced large amounts of text to smaller samples that explicitly and implicitly dealt with the issue of full participation. While analyzing these samples, we found patterns of different governance types in policy management that could plausibly be explained by social risk theory. The identified differences gave rise to different social citizenship themes. By contrasting these social citizen constructs that emerged in the analysis, with the issue of CRPD and full participation, we gained new insights into the management of social policies for people with disabilities. These insights are presented in Results and Analysis. 


\section{Results and Analysis}

\section{Governmental citizen-constructs and citizen responsibilities}

How a national government addresses its citizens reveals what it expects of them (cf. Larkin 2011). The analysis will, consequently, start by identifying the subject construct(s) that are used in the GP on Disability Policy. The exemplified extracts that are presented throughout this chapter are quotes from legal documents (authors' translation). The quotation below is the opening statement found in GP 2016/17:188 and has partly been the actualized view of people with disabilities since 1999/2000:

... the Government proposal identified the need of a paradigm and perspective shift that mediated a changed view of persons with disabilities. Such a changed view aimed for the need of leaving the care perspective where persons with disabilities were only viewed as care-objects, to a democratic perspective where people with disabilities have the right to participate in all parts of community life (p. 23).

However, the government found these policies insufficient and added to the new policies as part of its commitment to CRPD:

The concept of disability is nowadays a description of the interaction between persons with impairments and obstacles that are caused by attitudes and the environment, which counteracts the full and effective participation in society for persons with impairments, on equal terms with others (p. 24).

In the citations above, we identified a transition from the subject construct of 'the vulnerable patient in need of care', towards an empowering one; the autonomous democratic subject who is active in all parts of community life equal to the general population (cf. Markström 2003), which is found to be in line with CRPD and the new perspective on individuals with disabilities.

In relation to the quote above, the change of concepts from 'disability' to 'impairment' in policy texts transfers the locus of inability (to full participation) from the individual level to the societal level. This transfer of locus means that everyone is a potential active citizen and can be a full participant if society enables participation. The GP states that society - at all levels - must enable access so that individuals can enjoy their rights to full participation. Thus, full participation is the political goal that is to be fulfilled, and so, it is equally important that individuals take responsibility for their will to participate (regardless of the type of participation), otherwise they become their own obstacles to full participation. In line with 'no rights without responsibilities' in social risk theory (Kemshall 2002, 2010; Lister et al. 2011), the individual implicitly becomes 'responsibilized' for their life-course success - alongside with the government - and is expected to make the right decisions for themselves in line with contemporary social policies (see Mik-Meyer \& Villadsen 2013).

In the search for additional clarifications of the social-citizen construct, we found a constitutive quotation in Chapter 7 about the government's action-plans in the domain of labor market participation. This is a rare finding in relation to the explicit expectations on citizens: 
A well-functioning labor market that preserves human competencies, and will to work is the foundation of the Swedish welfare and competitiveness/... /humans want to contribute to the construction of society, and work creates enabling conditions for independency and self-determination/ ... /unemployment is additionally higher for people with disabilities compared to the rest of the population. The government goal is that the occupational rates shall increase for people with disabilities and unemployment decrease (Prop. 2016/17:188, p. 34-35).

First, it is interesting that the notions of moral obligations and citizen constructs in the document precede the description of the national action plans, since the quotation above is from the preamble of the chapter. The citizen construct sets the bar for further descriptions and policy actions, implying that the policies are founded on and are preconditioned by a certain citizen-type for the policies to function and goals to be fulfilled. The will to work and 'contribute to society' are highlighted in the GP as essential to Swedish welfare and are associated with the issue of morals and highly normative descriptions of citizen ambitions and expectations on ideal citizen traits, such as being a producer of welfare as a good working community member, and not 'just a consumer of welfare' (cf. Kvist et al. 2012, p. 6-7). Independence and self-determination are important key notions in the CRPD and the concept of full participation (Preamble, Article 3, 26b) and are here narrated as enabled through work, as a consequence of work. This implies a high degree of commodification through the narrative usage in this section where a person's independence and self-determination is dependent on their market contribution.

Next, we analyzed the same chapter for the goals and strategies addressed in the health area. When comparing the formulation of goals, we found that the emphasis and outcome of these goals differed:

The overall goal for the continuous work with public health is to create social conditions promoting good health on equal terms with the general public. People with disabilities rate their health worse than the rest of the public/... /The goal in the public health and medical care policies, is that the public shall be offered a needs-adjusted and effective health- and medical care of good quality. Such care shall be equal and accessible (Prop. 2016/17:188, p. 71).

Expectations on individual responsibility in the employment domain are explicitly formulated through the notions of morality and responsibility (the 'will to work' as being the essence of welfare). But explicit expectations on individual responsibility to participate in different life areas that are considered important to attain good health (cf. WHO 2001) - other than work - could not be found. The subject constructs and individual responsibilities found in health policies are implicit, such in the narrative usage of 'offering' provisions. The notion of offering presumes an outreach to active citizens who know where to turn for the offered help or support in relation to health issues, and have the ability to do so. Consequently, in line with the introductory quotations in the present section, individuals are described in the document as autonomous and empowered subjects. Similarities with the GP were found on issues of general public health (Prop. 2017/18:249, p. 9-10), where the subject constructs, in contrast, are described more explicitly in terms of responsibilities and making choices with caution, which is in line with social risk management in health policies (Kemshall 2002; Lupton 1993). 
The explicit versus implicit formulations in these policy areas, which are associated with active citizenship, emphasize higher expectations on individual responsibility in the labor market area. Moreover, implicit and explicit formulations in policy constructs have implications for policy implementation, which we will illustrate next in relation to how the government formulates its own responsibilities in the health and employment areas in disability policy.

\section{Governmental responsibilities in health and employment policies}

In the present section, we will analyze the governmental responsibilities of its citizens and how the government formulates its own role in the duality of responsibilization.

In Chapter 5 on national strategies and goals, we found explicit formulations in the national responsibility for fulfilling the vision of full participation in accordance with the CRPD:

... Sweden shall promote, protect and ensure the full and equal enjoyment of all human rights and fundamental freedoms/ ... / Equality in living conditions and full participation in society continue to be relevant and current goals (2017:188, p. 23).

By 'promoting, protecting and ensuring', the government makes clear its intentions for active responsibility. In general, these types of formulations are common throughout the document; general descriptions of how the national government narrates their responsibility in relation to people with disabilities in line with the CRPD. One area in disability policy that provides an illustrative example is the reasoning and formulations in 'the principle of universal design', which is emphasized as one of four important new branches in continuous national efforts towards fulfilling the rights of people with disabilities. The principle is described as follows:

... The principle of universal design is regarded by the government as a prioritized direction in the execution of disability policies./ ... /The principle does in this context not mean coercive regulations or any formal governance. Nor is the principle about adding costs, but shall be regarded as a guidance that enables considerations so that unnecessary obstacles for usage [accessibility] can be avoided (2016/17:188, p. 28).

In the above quotation, the legal document upholds the notion of 'universal design' as being prioritized. Universal design refers to accessibility (see UN CRPD 2006, Article $3,9)$, so that people with disabilities can participate on an equal basis with others; universal design is closely related to the issue of health and wellbeing (see WHO 2001). It is interesting, however, that soft governance is illustratively visible; directives are not mandatory but plausible if followed. Responsibility is delegated to different organizations through somewhat abstract directives, accompanied by a sanction-free assurance. In addition to the goals being managed through soft governance, the action plans in the document follow the same pattern where abstract directives and delegations constitute the governance of policies:

... the government has made an agreement with the Swedish Municipalities and Counties (SKL) ... to implement measures to improve the care of people with chronic diseases ... 
The National Board of Health and Welfare [Socialstyrelsen] should also distribute stimulant funds to representatives of patients' and professionals' organizations or other relevant organizations, for initiatives that contribute to better care for people with chronic illnesses. In addition, the National Food Agency [Livsmedelsverket] has been commissioned to promote the work on healthy eating habits in health care in order to prevent chronic diseases (Prop 2016/17:188, p. 72).

In this example, enabling active citizenship and full participation involves health in the form improving the life quality of individuals with chronic disease, and promoting healthy lifestyles through issues of nutrition. Rather than being the primary executor of policy implementation, the government takes on more of a monitoring function, relying on authorities' continuous work with 'implementing measures', 'contribute to better healthcare and healthy lifestyles', etc. A comparison of this type of formulation to the text found in the policy area of employment shows a large discrepancy between the nature of policy implementation:

The government have also raised the limit for the subsidized salary-costs for subsidized employments/... /the Government has assigned several authorities to create internship positions for the disposal of the Employment Service Agency and to receive unemployed persons with disabilities from the Employment Service Agency/ ... /Further the government has in the budget proposal of 2017 presented the investment in new preparation-jobs that will gradually be introduced from the year of 2017 and employ at least 5000 people in the year of $2020 /$... /employment provisions can be given during two years at the most, and 12 months at the time. (Prop. 2016/17:188, p. 36).

Detailed and different types of support-to-work schemes and regulations can be found in, for example, the illustrated quotation that describes how to fulfil the goal of full participation through work along with a specific number of people set to benefit from this new policy implementation. Here, detailed governance is visible, compared to the action plan in the public health domain or in the section of 'universal design'. This analytical section illustrates one of the many examples of soft and hard governance in a comparison of the employment and health-related policies that strive for active citizenship and full participation. In the literature, there is critique of the failure of some disability policies to achieve proper impact due to a lack of implementation of the policies and resources, including key authorities (Åkerberg 2011, p. 130; Sainsbury et al. 2017). The problem with policy implementation can partly be symptomatic of the absence of clear strategies to meet identified political needs. This results in spreading political risks through abstract directives and guidelines to diverse local organizations to manage in their own way (cf. Johansson 2011). Subsequently, the national government cannot as easily be blamed for the potential failure of policy implementation. This is an example of what Hvinden (2003) describes as the difference between operational intentions and intentions that remain nonpracticed. There is no such thing as pure hard or soft governance; there are always nuances of governance types (see Maycraft Kall 2010). But a clear difference can be found when comparing the two policy areas in the GP.

Analytically, we draw on the theory of social risks and see how these policy domains, which are both important policy areas, constitute different classes of risks. Public health and health-related policy issues are more of a long-term risk area; poor health can escalate 
with time and become an economic ‘burden' on society (see Lupton 1993; Kemshall 2002) if proper health and sick care, such as medicine, rehabilitation, counselling or nutrition, are not offered. But when a person becomes unemployed from one day to another, the social costs are immediate. The national government requires detailed control of frontline agency through hard-governed policy schemes (Maycraft Kall 2010, p. 12).

\section{Individual implications in relation to full participation and CRPD}

In this section, we link our findings on citizen-constructs and policy management, presented in the two previous analytical sections, to research and other legal documents. We also contrast labor market policies with health policies and contradictions found in relation to the CRPD.

A major GoR (SoU 2012:31) on the issue of disability and employment is referred to in the main legal document. The goal of the report is clearly stated in the document's introductory chapter. More efficient and faster employment provisions are highly prioritized and constitute a centralized goal in the ongoing work in the area of labor market integration of people with disabilities in Sweden, in line with active citizenry and full participation. Getting people off sick benefits or other social insurance benefit schemes in order to fill the financial gaps in other areas is also mentioned (2012:31, p. 344). The focus of the most recent GoR from 2018 (SoU 2018:21) is the same in in terms of efficacy, with the extra aim of developing a more flexible employment system with an intrinsic focus on support-to-work schemes and creating more work opportunities. The goal of higher employment rates is also clearly stated and in line with general tendencies in Europe (Sainsbury et al. 2017). These notions point to one aspect of employment: finding fulltime work for people with disabilities.

Other aspects of employment that are important from the perspectives of people with disabilities, such as job satisfaction, are not mentioned in the document more than in passing, for example, notions of social cohesion. Notions of meaningfulness, choice or self-determination in relation to offered jobs or vocational provisions are not mentioned, although these notions are considered to be vital to health and wellbeing (Bertilsdotter Rosqvist \& Keisu 2012; Bickenbach 2017; Prop. 2017/18:249; Deci \& Ryan 2008; Nouf-Latif et al. 2019a, 2019b; Pagán 2007). Rather, as research shows, the limits of self-determination are implicitly drawn at declining an offered job and is supplemented by continuous means testing for financial support that may be experienced as of a coercive nature (cf. Melén 2008; Grover \& Soldatic 2013; Johansson \& Hornemann Møller 2009; Wikström \& Ahnlund 2018) because monetary sanctions result if citizens handle their ascribed responsibility 'poorly' (see Kemshall 2002, 2010; Fritzell et al. 2012, p. 7; Lister et al. 2011; Melén 2008), that is, reduced economic benefits, or losing the entitlement to such benefits. Additionally, such economic sanctions violate an individual's rights to freely choose or accept offered jobs or re/habilitation programs, as addressed in Articles 26 and 27 in the CRPD (also see Article 3), which give access to disability benefits. Reduced economic benefits and the loss of entitlement to disability benefits follow when individuals reject offered jobs or choose to work less than their officially assessed working capacity, which is the same managerial approach as in general labor market policies. Nonetheless, the issue of equal treatment is raised in the GP on disability policy:

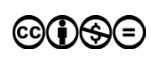


Equal opportunities do not always mean that the exact possibilities are given to everyone since equal treatment sometimes can lead to inequalities. Rather it [equal opportunities] recognizes individuals' differences and ensures, despite these differences, that everybody have the same opportunities to enjoy their rights ... (Prop. 2016/17:188, p. 16).

This quote draws on the issues of equality of opportunity and nondiscrimination (UN CRPD 2006, Article 3), which, for example, can be applied to support-to-work provisions aimed at full participation of people with disabilities. If fulltime work is not appropriate in the lives of some individuals to reach the goal of active citizenry and, thereby, full participation in all life areas, then part-time work with full-time economic benefits or a subsidized salary would be a plausible solution instead of individual sanctions. Denied disability benefits also lead to isolation due to a lack of means and, subsequently, poverty, which is a national and international concern in relation to people with disabilities (cf. Hansen et al. 2014; Prop. 2017/18:249, p. 14). In addition, accepting an unwanted job, or working more than what is individually assessed as the limit of a person's capacity may also lead to isolation. From this perspective, fulltime work may stand in opposition to, for example, social, physical, cultural or recreational activities (Article 30), or political participation (Article 29). These activities represent important participatory arenas as part of active citizenry and full participation but are implicitly denied to individuals whose physical or mental capacities are drained by participation in fulltime employment. This especially applies to women, who universally have lower employment rates than men and who, due to gender differences, are culturally obligated to take on more domestic responsibilities than men. This issue must be met by proper social services and support if equity is to be attained in the areas of family life and work (Pagán 2007; Prop. 2017/18:249; Halvorsen et al. 2017). In this context, the right to choose (see UN CRPD 2006, Preamble, Article 3, 26b) and the enjoyment of recreational activities are undermined in favor of Swedish employment policies and represent examples of components crucial to wellbeing and health (Aitchison 2009; Beresford \& Holden 2000; Nouf-Latif et al. 2019a). Structural barriers that block the potential of an individual to exercise these rights stand in opposition to Article 25 on the rights to the highest attainable standard of health with no discrimination on the basis of disability. Structural barriers are accounted for in ICF as obstacles to participation(s) in important life areas and, thereby, good health (WHO 2001).

However, research shows that labor market structures and economic incentives surpass individual incentives (Jacobsson \& Seing 2013; Larkin 2011) and call for a need to rethink work from a critical perspective in parallel with the implementation of different labor market policies and schemes around Europe that focus on normative and static aspects of working life (Bertilsdotter Rosqvist \& Keisu 2012; Sainsbury et al. 2017). These aspects include fulltime paid employment instead of individual measures for meaningful or satisfactory work (cf. Nouf-Latif et al. 2019a, 2019b).

Having the capacity to work fulltime does automatically mean, in Sweden, that you are not work-disabled and can work fulltime (see Melén 2008, p. 182). The Employment Service Agency [Arbetsförmedlingen] and the Social Insurance Agency [Försäkringskassan] are two key authorities in Sweden that collaborate on the issue of assessing work capacity and finding proper support-to-work placements, vocational rehabilitation or ordinary employment (Jacobsson \& Seing 2013; Melén 2008). The SIA has received a great deal of critique in media in recent years for being inhumane in its management of 
sick leaves or unemployment (e.g., Försäkringskassan 2015, p. 70; Dagens arbete 2018). Thus, the consequences of working fulltime and having no energy left for any other participatory activity after work is not accounted for in present labor market/employment policies, since fulltime individual capacity for work exists. From this perspective, there is no individual work-related disability for the ESA to aid. In tandem, alarming numbers of individuals with no social, political or recreational activities and with low rates of good health are addressed in the legal document.

There is an ambiguity in adopting the CRPD and the vision of full participation through any type of employment and fulltime work. Full participation, in its essence, is not synonymous with work but rather addresses the issue of work as one of many important aspects of attaining healthy active citizenry and full participation. This is illustrated in the GP that connects the issue of public health with all life areas (Prop 2017/18:249), a document that targets the Swedish population in general and not only people with disabilities.

However, having a job does not, of course, mean that the risk of acquiring ill health disappears. Work can give structure to life, contribute to personal development and be health-promoting, but it can also worsen health/ .../the type of employment ... affect the ability to balance work-life, domestic work and family-life./ ... /Other important psychosocial factors that are crucial for work-related ill health are job insecurity, lack of balance between effort and reward, long working hours ... (Prop. 2017/18:249, p. 65).

The focus of the national goals in disability policies circles around the CRPD, where employment is detailed in policy implementation, but important linkages between health and work are not accounted for. Further, in the GP on public health (2017/18:249), the government states:

Employers on the market, authorities, county council, and municipalities are important agents in the work on public health, since they can improve health among their employees. The work environment, but also e.g. different types of employment and possibilities of creating a balance between work and leisure, are of importance in achieving good health (Prop. 2017/18:249, p. 30).

Eleven authorities are listed as being especially important in work with promoting good health, but none of them include the ESA. The issue of health is addressed with regard to leisure and work. The issue of incorporating strategies to promote health by balancing leisure and work is framed as a general directive for employers rather than a political goal that is incorporated into employment policies. This is an internationally relevant issue in general research on intensified demands on the labor market in combination with struggles to find a work/leisure balance (e.g., Haworth \& Lewis 2005) and is not addressed in the GP on disability policy. In another legal document, however, a contradictory view is presented where informational material on how an individual's impairment affects the person in daily life, is regarded as nonapplicable for an employee in a vocational re/habilitation process or in an employment process (SoU 2018:21, p.118). How daily life can be irrelevant to support-to-work provisions and individual job matching is logically disjointed. The distinction made counteracts Article 26, which explicitly states that all social services or re/habilitation programs shall depart from individual needs and strengths and aim for full inclusion and participation in all aspects of life. 


\section{Conclusions and Final Remarks}

Active subject constructs are addressed in both subareas of employment and health in disability policies, accompanied by implicit and explicit governmental expectations on individual responsibilities to practice active citizenry. However, employment and public health constitute different social risk areas where the employment domain holds a higher social risk status than health does, due to the immediate social expenditures derived from unemployment. Our findings show that the national government's responsibility is profound in terms of employment policies that are managed through hard governance to counteract the social risk of unemployment. Governmental responsibility in the health policy area is present, although it is managed through soft governance with abstract directives to stakeholder organizations or authorities. The soft and hard governance types are reflected both in how policies are formulated and implemented.

The individual implications of how the policies are implemented in terms of full participation - with CRPD as the new cloak - suggest a cherry picking of disability rights. We identified a hazard in ascribing unemployment a higher social risk status than health, since health is the foundation that determines workability and enables other important aspects of wellbeing, such as social engagement or recreational activities, as stipulated in the CRPD. Thus, work as an activity itself does not have the same consequences for 'life' as health does, but the economic dimension of work is nonetheless crucial. In line with expectations and demands on the individual in contemporary employment policies and the risk of economic sanctions, individuals with disabilities are obliged to accept any employment, or work more than they personally assess they have the capacity to. The conditioning of CRPD-related notions of self-determination, choice and possibilities to practice community-related activities is palpable considering the strong political emphasis on, and hard governance of, fulltime work participation and work capacity (cf. Melén 2008). This clashes with other components of active citizenry and full participation. Being an active citizen, who fully participates in all important life areas in accordance with Swedish disability policies and CRPD, entails much more than vocational participation (Halvorsen et al. 2017; Sainsbury et al. 2017). However, economic incentives in Swedish labor market policy (Arbetslinjen) are strongly driven by the Swedish government and overshadow other policy areas and, subsequently, individual needs. We identified an imbalance in the policy management of full participation that is caused by structural barriers, and the opportunities of individuals to enjoy the rights emphasized as important to health and wellbeing, active citizenry and thereby full participation.

Work can be an important piece in the puzzle of wellbeing according to research, with major benefits for an individual's sense of meaningfulness, autonomy, identity and participation in society (e.g., Gibson et al. 2014; Nouf-Latif et al. 2019a, 2019b). Nonetheless, work can have a negative impact on an individual's sense of wellbeing if it does not match individual preferences and needs in terms of work-life balance and working life (Bertilsdotter Rosqvist \& Keisu 2012; Laurence 2015; Nouf-Latif et al. 2019a; Tsaousides $\&$ Jome 2008). Other life areas encompassing participatory and socially inclusive functions for the individual that are accounted for in CRPD should be included in a more holistic approach in support-to-work services and habilitation services (cf. Renty \& Roeyers 2006; UN CRPD 2006, Articles 26, 27). These are life areas that have an impact on health, and represent areas that are reported to be insufficiently enjoyed by people with disabilities 
in Sweden (Prop. 2016/17:188). Therefore, an individual's life situation and preferences should be taken into account in vocational services and not only the individual's degree of workability. We especially emphasize the realization of the right to a sanction-free choice and equality of opportunity (UN CRPD 2006, Preamble, Articles 3, 26, 27, 29, 30) in relation to all kinds of employment or vocational re/habilitation services.

Our findings indicate the same pattern as found in larger social policy trends in Europe. The result of handling the social risk of unemployment has, in the Nordic countries, Europe, Australia and other western countries, turned into a welfare-to-workfare project (Jacobsson \& Seing 2013; Larkin 2011; Soldatic \& Chapman 2010; Wright 2012). In line with the contemporary western political context that manages social risk through ALMP and detailed governance to ensure proper organizational management, the emphasis on and governance of employment in disability policies implicitly neglect important aspects in relation to health-related notions of work-life balance.

We also identified the need for the concrete inclusion of different CRPD-related notions of health/full participation in present support-to-work schemes to avoid the neglect of this issue and to ensure that hard governance is used as a tool to attain a broader notion of full participation in Swedish disability policies. Hard governance is a debated issue where the interaction between professionals and service users takes place. State officials, who work in direct interaction with clients, may deprioritize their professional instincts concerning client needs due to mandatory compliance with standardized policy schemes (cf. Johansson 2011; Morén et al. 2015). We suggest an adaption to the contemporary situation with hard governance, by balancing the social policy equation and incorporating firm directives into social policy schemes that benefit individuals with disabilities from the perspective of CRPD as a whole, which is not limited to fulltime employment.

\section{References}

Aitchison, C. (2003). From leisure and disability to disability leisure: developing data, definitions and discourses, Disability \& Society 18(7): 955-969. doi: http://doi.org/10.1080/ 0968759032000127353.

Åkerberg, A. (2011). Svenska funktionshindersrörelsens alternativrapport till FN: s kommitté för rättigheter för personer med funktionsnedsättning [The Swedish disability movement's alternative report to the UN committee of rights for people with disabilities], Projekt Agenda 50. Retrieved November 14, 2018 from https://www.testwebben. se/4580/Filer/Funktionshindersrorelsens Alternativrapport 2011.pdf.

Barnes, C. (2000). A working social model? Disability, work and disability politics in the 21st century, Critical Social Policy 20(4): 441-457. doi: http://doi.org/10.1177/02610 1830002000402.

Barnes, C. \& Mercer, G. (2005). Disability, work, and welfare: challenging the social exclusion of disabled people, Work, Employment \& Society 19(3): 527-545. doi: http://doi.org/ $10.1177 / 0950017005055669$.

Beresford, P. \& Holden, C. (2000). We have choices: globalisation and welfare user movements, Disability and Society 15(7): 973-989. doi: http://doi.org/10.1080/713662017.

Bergmark, M., Bejerholm, U. \& Markström, U. 2017. Policy changes in community mental health: interventions and strategies used in Sweden over 20 years, Social Policy \& Administration 51(1): 95-113. doi: http://doi.org/10.1111/spol.12175. 
Bertilsdotter Rosqvist, H. \& Keisu, B-I. (2012). Adaption or recognition of the autistic subject? - reimagining an autistic work life: deconstructing the notion of 'real jobs' within the Swedish neurodiverse movement, Journal of Vocational Rehabilitation 37(3): 203-212. doi: https://doi.org/10.3233/JVR-2012-0615.

Brandsen, T., Boogers, M. \& Tops, P. (2006). Soft governance, hard consequences: the ambiguous status of unofficial guidelines, Public Administration Review 66(4): 546-553. doi: http://doi.org/10.1111/j.1540-6210.2006.00615.x.

Bickenbach, J. (2017). How do we know whether changes in public policy and legislation improve the conditions for exercising Active Citizenship by persons with disabilities. In: The Changing Disability Policy System: Active Citizenship and Disability in Europe, Taylor and Francis.

Cantillon, B. \& Van Lancker, W. (2013). Three shortcomings of the social investment perspective, Social Policy and Society 12(4): 553-564. doi: http://doi.org/10.1017/S1474 746413000080 .

Clark, A. E. (1998). Measures of Job Satisfaction: What Makes a Good Job? Evidence from OECD Countries, OECD Labour Market and Social Policy Occasional Papers (34): 1-42. doi: http://doi.org/10.1787/670570634774.

Dagens arbete (2018). Ett helt sjukt system [A completely sick system]. Retrieved June 1, 2019, from: https://da.se/2018/03/ett-helt-sjukt-system/.

Deci, E. L. \& Ryan, R. M. (2008). Self-determination theory: A macrotheory of human motivation, development, and health, Canadian Psychology/Psychologie Canadienne 49(3): 182. doi: http://doi.org/10.1037/a0012801.

Esping-Andersen, G. (1999). Social Foundations of Postindustrial Economies, OUP Oxford.

Evans, T. \& Harris, J. (2004). Street-level bureaucracy, social work and the (exaggerated) death of discretion, The British Journal of Social Work 34(6): 871-895. doi: http://doi. org/10.1093/bjsw/bch106.

Fritzell, J., Bäckman, O. \& Ritakallio, V. M. (2012). Income inequality and poverty: do the Nordic countries still constitute a family of their own. In: Changing social equality The Nordic welfare model in the 21st century, Bristol: Policy Press.

Gibson, B., Mistry, B., Smith, B., Yoshida, K., Abbott, D., Lindsay, S. \& Hamdani, Y. (2014). Becoming men: gender, disability, and transitioning to adulthood, Health 18(1): 95-114. doi: http://doi.org/10.1177/1363459313476967.

Grover, C. \& Soldatic, K. (2013). Neoliberal restructuring, disabled people and social (in) security in Australia and Britain, Scandinavian Journal of Disability Research 15(3): 216-232. doi: http://doi.org/10.1080/15017419.2012.724446.

Halvorsen, R. \& Hvinden, B. (2014). Nordic reforms to improve the labour market participation of vulnerable youth: an effective new approach? International Social Security Review 67(2): 29-47. doi: http://doi.org/10.1111/issr.12037.

Halvorsen, R., Hvinden, B., Bickenbach, J., Ferri, D. \& Guillén Rodríguez, A. (2017). Revisiting the multi-level and multi-actor framework. In: The Changing Disability Policy System: Active Citizenship and Disability in Europe, Taylor and Francis.

Hansen, H., Bourgois, P. \& Drucker, E. (2014). Pathologizing poverty: new forms of diagnosis, disability, and structural stigma under welfare reform, Social Science \& Medicine (103): 76-83. doi: http://doi.org/10.1016/j.socscimed.2013.06.033.

Haworth, J. \& Lewis, S. (2005). Work, leisure and well-being, British Journal of Guidance \& Counselling 33(1): 67-79. doi: http://doi.org/10.1080/03069880412331335902.

Hsieh, H. F. \& Shannon, S. E. (2005). Three approaches to qualitative content analysis, Qualitative Health Research 15(9): 1277-1288. doi: https://doi.org/10.1177/10497323052 76687.

Hvinden, B. (2003). The uncertain convergence of disability policies in western Europe, Social Policy \& Administration 37(6): 609-624. doi: http://doi.org/10.1111/1467-9515.00361. 
Hvinden, B. Halvorsen, R. Bickenbach, J. Ferri, D. \& Guillén, A.M. (2017). Is public policy in Europe promoting the Active Citizenship of persons with disabilities? In: The Changing Disability Policy System: Active Citizenship and Disability in Europe, Taylor and Francis.

Jacobsson, K. \& Seing, I. (2013). En möjliggörande arbetsmarknadspolitik? Arbetsförmedlingens utredning och klassificering av klienters arbetsförmåga, anställbarhet och funktionshinder [An enabling labour market policy? The Employment Service Agency's inquest and classification of clients' work-ability, employability and disability] Arbetsmarknad \& arbetsliv 19(1): 9-24.

Johansson, S. (2011). Who runs the mill? - The distribution of power in Swedish social service agencies, European Journal of Social Work 15(5): 679-695. doi: http://doi.org/10.1 080/13691457.2011.594424.

Johansson, H. \& Hornemann Møller, I. (2009). Vad menar vi med aktivering? [what do we mean by activation?], Stockholm: Liber.

Kemshall, H. (2002). Effective practice in probation: an example of 'advanced liberal' responsibilisation? The Howard Journal of Criminal Justice 41(1): 41-58. doi: http://doi. org/10.1111/1468-2311.00224.

Kemshall, H. (2010). Risk rationalities in contemporary social work policy and practice, The British Journal of Social Work 40(4): 1247-1262. doi: http://doi.org/10.1093/bjsw/bcp157.

Kvist, J., Fritzell, J., Hvinden, B. \& Kangas O. (2012). Changing social inequality and the Nordic welfare model. In: Changing social equality. The Nordic welfare model in the $21 \mathrm{st}$ century, Bristol: Policy Press.

Larkin, P. (2011). Incapacity, the labour market and social security: coercion into 'positive' citizenship, The Modern Law Review 74(3): 385-409. doi: https://oi.org/10.1111/ j.1468-2230.2011.00852.x.

Laurence, J. (2015). (Dis)Placing trust: the long-term effects of job displacement on generalised trust over the adult lifecourse, Social Science Research (50): 46-59. doi: http://doi. org/10.1016/j.ssresearch.2014.11.006.

Lister, R. (2003). Investing in the citizen-workers of the future: transformations in citizenship and the state under new labour. Social Policy \& Administration 37(5): 427-443. doi: http://doi.org/10.1111/1467-9515.00350.

Lister, R., Holden, C., Kilkey, M. \& Ramia, G. (2011). The age of responsibility: social policy and citizenship in the early 21st century, Social Policy Review (23): 63-84.

Lupton, D. (1993). Risk as moral danger: the social and political functions of risk discourse in public health, International journal of health services 23(3): 425-435. doi: http://doi. org/10.2190/16AY-E2GC-DFLD-51X2.

Madsen, P. K. (2008). The Danish road to 'flexicurity': Where are we compared to others? And how did we get there. In: Flexibility and Employment Security in Europe: Labour Markets in Transition, Edward Elgar Publishing.

Markström, U. (2003). Den Svenska Psykiatrireformen: Bland Brukare, Eldsjälar och Byråkrater [The Swedish Mental Health Reform: Among Users, Driving Spirits and Bureaucrats], Borea: Finland.

Maycraft Kall, W. (2010). The Governance Gap: Central-local steering \& mental health reform in Britain and Sweden. Dissertation, Statsvetenskapliga föreningen i Uppsala.

Melén, D. (2008). Sjukskrivningssystemet - Sjuka som blir arbetslösa och arbetslösa som blir sjukskrivna [The sick-leave system - sick who get unemployed and unemployed who get sick] (79): Dissertation, Lund University.

Mik-Meyer, N. \& Villadsen, K. (2013). Power and welfare: understanding citizens' encounters with state welfare, London: Routledge.

Morén, S., Perlinski, M. \& Blom, B. (2015). En domänteori för organisering av socialt arbete i offentlig sektor [A domain theory for organizing social work in the public sector], Socialvetenskaplig tidskrift 22(1): 22-43. 
Määttä, M. \& Eriksson, K. (2014). Network governance and programme steering - rationales and tensions in planning child and youth policies, Social Policy \& Administration 49(5): 631-648. doi: http://doi.org/10.1111/spol.12097.

Newman, J. \& Tonkens, E. (2011). Participation, Responsibility and Choice: Summoning the Active Citizen in Western European Welfare States, Amsterdam: University Press.

Nouf-Latif, F. Bertilsdotter-Rosqvist, H. \& Markström, U. (2019a). Narratives of ideal and second-option jobs among young adults with high functioning autism, Nordic Social Work Research 9(2): 104-117. doi: https://doi.org/10.1080/2156857X.2018.1484385.

Nouf-Latif, F. Andersson, K. \& Markström, U. (2019b). Encouraging real or make-believe citizen-workers? Narratives of self-realization versus disabling support-to-work contexts by individuals with High Functioning Autism, Alter 13(2): 126-140. doi: https://doi. org/10.1016/j.alter.2019.03.001.

Organisation for Economic Co-operation and Development (OECD) (2010). Sickness, disability and work: Breaking the barriers. A synthesis of findings across OECD countries.

Organisation for Economic Co-operation and Development (OECD) (2015). Fit Mind, Fit Job: From Evidence to Practice in Mental Health and Work, OECD Publishing, Paris. doi: https://dx.doi.org/10.1787/9789264228283-9-en.

Pagán, R. (2007). Is part-time work a good or bad opportunity for people with disabilities? A European analysis, Disability and Rehabilitation 29(24): 1910-1919. doi: http://doi. org/10.1080/09638280701192881.

Pearson, Q. M. (2008). Role overload, job satisfaction, leisure satisfaction, and psychological health among employed women, Journal of Counseling \& Development 86(1): 57-63. doi: https://doi.org/10.1002/j.1556-6678.2008.tb00626.x.

Piippola, S. (2010). Arbetslinjen - social trygghet eller risk? [The work-line -social security or risk?] Socialvetenskaplig Tidskrift 17(3-4): 255-269.

Prop. 2016/17:188. Nationellt mål och inriktning för funktionshinderspolitiken [national goal and alignment of disability policies]. Retrieved 14 November 2018 from https:// www.regeringen.se/49aa12/contentassets/0571a7504d49428292a6ab114e4b0263/nationellt-mal-och-inriktning-for-funktionshinderspolitiken-prop-2016-17 188.pdf.

Prop. 2017/18:249. God och jämlik hälsa - en utvecklad folkhälsopolitik. [Good and equal health - a developed public health policy] Retrieved 14 November 2018 from https:// www.regeringen.se/498282/contentassets/8d6fca158ec0498491f21f7c1cb2fe6d/prop.201718 249-god-och-jamlik-halsa--en-utvecklad-folkhalsopolitik.pdf.

Powell, M. \& Barrientos, A. (2004). Welfare regimes and the welfare mix, European Journal of Political Research (43): 83-105. doi: https://doi.org/10.1111/j.1475-6765.2004.00146.x.

Regeringen (2018). Swedish legislation - how laws are made. Retrieved 21 May 2019 from https:// www.government.se/how-sweden-is-governed/swedish-legislation---how-laws-are-made/.

Renty, J. \& Roeyers, H. (2006). Quality of life in high-functioning adults with autism spectrum disorder: the predictive value of disability and support characteristics, Autism 10(5): 511-524. doi: http://doi.org./10.1177/1362361306066604.

Rose, N. (1999). Powers of Freedom - Reframing Political Thought, Cambridge: Cambridge University Press. doi: https://doi.org/10.1017/CBO9780511488856.

Sainsbury, R., Coleman-Fountain, E., \& Trezzini, B. (2017). How to enhance Active Citizenship for persons with disabilities in Europe through labour market participation: European and national perspectives. In: The Changing Disability Policy System: Active Citizenship and Disability in Europe, Taylor and Francis.

Försäkringskassan (2015). Förtroendet för Försäkringskassan 1999-2010 [the confidence in Försäkringskassan 1999-2010], Socialförsäkringsrapport 2015:8, Stockholm: Försäkringskassan. Retrieved June 1, 2019, from https://www.forsakringskassan.se/ wps/wcm/connect/81d0e277-a54e-4bd8-ac61-8edd300e7a92/socialforsakringsrapport 2015 08.pdf?MOD=AJPERES. 
Soldatic, K. \& Chapman, A. (2010). Surviving the assault? The Australian disability movement and the neoliberal workfare state, Social Movement Studies 9(2): 139-154. doi: http://doi.org/10.1080/14742831003603299.

SoU 2012:31. Sänkta trösklar - högt I tak, Arbete, utveckling, trygghet [lowered thresholds high ceilings. Work, development and security]. Retrieved November 14, 2018, from https://www.regeringen.se/49baed/contentassets/75f6bb7710aa4010813b99eff0167a80/ sankta-trosklar-hogt-i-tak.-arbete-utveckling-trygghet-kapitel-1-4-sou-201231.

SoU 2018:21. Flexibel rehabilitering [flexible rehabilitation]. Retrieved November 14, 2018, from https://www.regeringen.se/494694/contentassets/75ed05f990ac427a96f84b41f9737e2d/flexibel-rehabilitering-sou-201821.

Tsaousides, T. \& Jome, L. (2008). Perceived career compromise, affect and work-related satisfaction in college students, Journal of Vocational Behavior 73(2): 185-194. doi: http:// doi.org/10.1016/j.jvb.2008.04.003.

United Nations (2006). Convention on the rights of persons with disabilities (CRPD). Retrieved June 1, 2019, from https://www.un.org/disabilities/documents/convention/convoptprot-e.pdf.

UPIAS (1976). Fundamental Principles of Disability, London: Union of the Physically Impaired Against Segregation.

Yeh, H-J. (2015). Job demands, job resources, and job satisfaction in East Asia, Social Indicators Research 121(1): 47-60. doi: http://doi.org/10.1007/s11205-014-0631-9.

Wikström E. \& Ahnlund, P. (2018). Making refugees work? Individualized work strategies in the Swedish Refugee settlement program, Nordic Journal of Working Life Studies 8(4): 47-65. doi: https://doi.org/10.18291/njwls.v8iS4.111157.

World Health Organization (WHO) (2001). International classification of functioning, disability and health, Geneva: World Health Organization.

Wright, S. (2012). Welfare-to-work, agency and personal responsibility, Journal of Social Policy 41(2): 309-328. doi: http://doi.org/10.1017/S0047279411001000. 